\title{
SIMPLIFIED PROOF OF TANAHASHI'S RESULT ON THE BEST POSSIBILITY OF GENERALIZED FURUTA INEQUALITY
}

\author{
TAKEAKI YAMAZAKI
}

Abstract. We give a simplified proof of Tanahashi's result on the best possibility of generalized Furuta inequality by using Tanahashi's result on the best possibility of Furuta inequality.

Mathematics subject classification (1991): 47A63.

Key words and phrases: positive operator, Furuta inequality, generalized Furuta inequality.

\section{REFERENCES}

[1] T. ANDO, On some operator inequalities, Math. Ann., 279 (1987), 157-159.

[2] T. ANDO AND F. HIAI, Log majorization and complementary Golden-Thompson type inequalities, Linear Algebra Appl., 197, 198 (1994), 113-131.

[3] M. FuJII, Furuta's inequality and its mean theoretic approach, J. Operator Theory, 23 (1990), 67-72.

[4] M. FUJII, T. FuRUTA AND E. KAMEI, Furuta's inequality and its application to Ando's theorem, Linear Algebra Appl., 179 (1993), 161-169.

[5] M. FuJII, J. F. JIANG AND E. KAMEI, Characterization of chaotic order and its application to Furuta inequality, Proc. Amer. Math. Soc., 125 (1997), 3655-3658.

[6] M. FuJII AND E. KAMEI, Mean theoretic approach to the grand Furuta inequality, Proc. Amer. Math. Soc., 124 (1996), 2751-2756.

[7] M. Fuji, A. Matsumoto AND R. NAKAmoto, A short proof of the best possibility for the grand Furuta inequality, preprint.

[8] T. FurutA, $A \geqslant B \geqslant 0$ assures $\left(B^{r} A^{p} B^{r}\right)^{1 / q} \geqslant B^{(p+2 r) / q}$ for $r \geqslant 0, p \geqslant 0, q \geqslant 1$ with $(1+2 r) q \geqslant p+2 r$, Proc. Amer. Math. Soc., 101 (1987), 85-88.

[9] T. FURUTA, An elementary proof of an order preserving inequality, Proc. Japan Acad., 65 (1989), 126.

[10] T. FURUTA, Applications of order preserving operator inequalities, Oper. Theory Adv. Appl., 59 (1992), 180-190.

[11] T. FURUTA, Extension of the Furuta inequality and Ando-Hiai log-majorization, Linear Algebra Appl., 19 (1995), 139-155.

[12] T. FURUTA, Simplified proof of an order preserving operator inequality, Proc. Japan Acad., 74 (1998), 114.

[13] T. FuRUTA, M. HASHIMOTO AND M. ITO, Equivalence relation between generalized Furuta inequality and related operator functions, Scientiae Mathematicae, 1 (1998), 257-259.

[14] T. FURUTA AND D. WANG, A decreasing operator function associated with Furuta inequality, Proc. Amer. Math. Soc., 126 (1998), 2427-2432.

[15] T. FURUTA, T. YAMAZAKI AND M. YANAGIDA, Operator functions implying generalized Furuta inequality, Math. Ineq. Appl., 1 (1998), 123-130.

[16] T. Furuta, T. YAMAZAKI AND M. YANAGIDA, Order preserving operator inequalities via Furuta inequality, Math. Japon., 48 (1998), 471-476.

[17] T. FURUTA, T. YAMAZAKI AND M. YANAGIDA, Order preserving operator function via Furuta inequality “ $A \geqslant B \geqslant 0$ ensures $\left(A^{\frac{r}{2}} A^{p} A^{\frac{r}{2}}\right)^{\frac{1+r}{p+r}} \geqslant\left(A^{\frac{r}{2}} B^{p} A^{\frac{r}{2}}\right)^{\frac{1+r}{p+r}}$ for $p \geqslant 1$ and $r \geqslant 0$ ”, to appear in Proc. 96-IWOTA.

[18] E. KAMEI, A satellite to Furuta's inequality, Math. Japon., 33 (1988), 883-886. 
[19] K. Tanahashi, Best possibility of the Furuta inequality, Proc. Amer. Math. Soc., 124 (1996), 141-146.

[20] K. TANAHASHI, The best possibility of the grand Furuta inequality, to appear in Proc. Amer. Math. Soc.

[21] M. YANAGIDA, Some applications of Tanahashi's result on the best possibility of Furuta inequality, to appear in Math. Ineq. Appl. 